OPEN ACCESS

Edited by:

Kyung-Yil Lee,

The Catholic University of Korea,

South Korea

Reviewed by:

Diego F. Coutinho,

New York University, United States

Hongryang Kil,

Chungnam National University,

South Korea

${ }^{*}$ Correspondence:

Surjit Singh

suritsinghpgi@rediffmail.com

Specialty section: This article was submitted to

Pediatric Immunology

a section of the journal

Frontiers in Pediatrics

Received: 16 January 2019 Accepted: 28 May 2019

Published: 18 June 2019

Citation:

Chaudhary $\mathrm{H}$, Nameirakpam J, Kumrah R, Pandiarajan V, Suri $D$

Rawat $A$ and Singh S (2019)

Biomarkers for Kawasaki Disease:

Clinical Utility and the Challenges

Ahead. Front. Pediatr. 7:242.

doi: 10.3389/fped.2019.00242

\section{Biomarkers for Kawasaki Disease: Clinical Utility and the Challenges Ahead}

\section{Himanshi Chaudhary, Johnson Nameirakpam, Rajni Kumrah, Vignesh Pandiarajan, Deepti Suri, Amit Rawat and Surjit Singh*}

Post Graduate Institute of Medical Education and Research, Chandigarh, India

Kawasaki disease $(K D)$ has replaced acute rheumatic fever as the most common cause of acquired heart disease in children in the developed world and is increasingly being recognized from several developing countries. It is a systemic vasculitis with a predilection for coronary arteries. The diagnosis is based on a constellation of clinical findings that appear in a temporal sequence. Quite understandably, this can become a problem in situations wherein the clinical features are not typical. In such situations, it can be very difficult, if not impossible, to arrive at a diagnosis. Several biomarkers have been recognized in children with acute KD but none of these has reasonably high sensitivity and specificity in predicting the course of the illness. A line up of inflammatory, proteomic, gene expression and micro-RNA based biomarkers has been studied in association with KD. The commonly used inflammatory markers e.g. erythrocyte sedimentation rate (ESR), C-reactive protein (CRP), and total leucocyte counts (TLC) lack specificity for KD. Proteomic studies are based on the identification of specific proteins in serum, plasma and urine by gel electrophoresis. A host of genetic studies have identified genes associated with $\mathrm{KD}$ and some of these genes can predict the course and coronary outcomes in the affected individuals. Most of these tests are in the early stages of their development and some of these can predict the course, propensity to develop coronary artery sequelae, intravenous immunoglobulin (IVIg) resistance and the severity of the illness in a patient. Development of clinical criteria based on these tests will improve our diagnostic acumen and aid in early identification and prevention of cardiovascular complications.

Keywords: immunology, vasculitis, Kawasaki, biomarkers, childhood vasculitis

\section{INTRODUCTION}

Kawasaki disease $(\mathrm{KD})$ is a common childhood vasculitis. The disease was first described in Japanese children in 1967 by a Japanese pediatrician, Dr. Tomisaku Kawasaki (1). The highest incidence is seen in Japan, Korea and Taiwan (2). However, the disease is now being reported world over including several developing countries like India (3-7). 
The diagnosis of KD is essentially clinical (8). The clinical features mimic many self-resolving exanthematous febrile illnesses of childhood (e.g., measles, adenoviral infection, scarlet fever, dengue fever). These illnesses share some common clinical features with $\mathrm{KD}$ like fever, rash, mucocutaneous manifestations, lymphadenopathy, and elevated inflammatory parameters. The diagnosis of KD can be easily missed if the cascade of clinical findings goes unrecognized especially in cases of incomplete KD. Things can get even more complicated when KD occurs in association with an infection. The associated coronary artery abnormalities (CAAs) may go undetected and can have significant long-term implications if treatment is not initiated at the right time. Unlike other vasculitides and other rheumatological disorders, there are no pathognomonic laboratory tests for diagnosis of this condition. For the treating clinician, it is often difficult to confirm a diagnosis of KD on the bedside. It is, therefore, important to establish a set of laboratory markers that are sensitive, specific, reproducible and help the treating pediatrician in arriving at a diagnosis. As intravenous immunoglobulin (IVIg) is an expensive product, it is imperative that it be used only in situations where it is definitely indicated. However, in a setting of incomplete KD, the pediatrician often faces the dilemma of under-treatment with its attendant risks of CAAs vs. using IVIg in circumstances where it may not really be indicated.

Several biomarkers have been studied in association with $\mathrm{KD}$ and some of these have been shown to be predictive of resistance to IVIg while others may be indicative of an increased risk of development of CAAs. This manuscript overviews some of the important biomarkers that have been studied in $\mathrm{KD}$ and highlights their role in the diagnosis and assessment of disease severity.

\section{INFLAMMATORY BIOMARKERS (TABLE 1)}

These are the conventional biomarkers that mirror inflammatory activity and are not specific to KD. Erythrocyte sedimentation rate (ESR) is consistently elevated during the acute phase of $\mathrm{KD}$ but may be unreliable as a marker of disease activity after the administration of IVIG (9-11). There is neutrophilic leukocytosis during the acute phase of the disease and the degree of leukocytosis has been correlated with myocardial dysfunction $(10,12)$. Thrombocytosis, usually seen after the completion of the first week of illness, is a marker of ongoing inflammation. Persistent thrombocytosis has been linked to the development of CAAs but the association is tenuous $(9,18)$. C-reactive protein (CRP) is known to have a significant association with disease severity and the development of CAAs $(9,10,12)$. Procalcitonin levels have been shown to be elevated during the acute phase and this rise is especially marked in children with resistance to IVIg $(13,16)$. Peripheral blood eosinophilia (PBE) (17) and low albumin has been associated with increased risk of IVIG resistance and coronary complications (14). Low mean platelet volume (MPV) (15), platelet distribution width (PDW) (19), and platelet-derived microparticles (PDMP) (20) have been shown to be markers of platelet activation and inflammation in acute stages of $\mathrm{KD}$. However, their use as biomarkers for the disease requires replication of results across different populations.

\section{Summary}

Inflammatory markers are largely nonspecific as these are also elevated in many other inflammatory and infective conditions. In a clinical setting of $\mathrm{KD}$, while these biomarkers can reflect ongoing inflammation, they are of limited use in arriving at a definitive diagnosis.

\section{IMMUNOLOGICAL MARKERS (TABLE 2) Cellular Markers Innate Immunity}

Myeloid dendritic cells (mDCs), which serve as a bridge between adaptive and innate immunity, have been shown to be decreased in acute KD. Takahashi et al. (21) have suggested that decreased levels are due to either recirculation into affected tissues or

TABLE 1 | Inflammatory biomarkers of Kawasaki disease.

\begin{tabular}{|c|c|c|c|}
\hline Parameter & Normal values & Comment & References \\
\hline Erythrocyte sedimentation rate (ESR) & 0-22 mm/h & $\begin{array}{l}\text { - Increased in acute phases } \\
\text { - Unreliable for monitoring response to IVIG therapy }\end{array}$ & $(6-8)$ \\
\hline Total leucocyte count(TLC) & $4-11 \times 109 / L$ & $\begin{array}{l}\text { - Higher counts associated with higher risk of CAAs } \\
\text { - High in patients with delayed diagnoses of KD }\end{array}$ & $(9-12)$ \\
\hline Platelet count & $150-400 \times 109 / L$ & $\begin{array}{l}\text { Increased in acute stage and prolonged thrombocytosis } \\
\text { associated with increased risk of CAAs }\end{array}$ & $(6,13)$ \\
\hline Mean platelet volume(MPV) & $7-11 \mathrm{fl}$ & Low values increase the likelihood of CAAs & $(14)$ \\
\hline Platelet distribution width(PDW) & $10.0-17.9 \%$ & $\begin{array}{l}\text { High values suggest platelet activation and increase the } \\
\text { likelihood of CAAs }\end{array}$ & $(15)$ \\
\hline C-Reactive protein(CRP) & $<10 \mathrm{mg} / \mathrm{L}$ & Prediction of cardiac sequelae, age-dependent prognosis & $(10,11,13)$ \\
\hline Procalcitonin & $<0.15 \mathrm{ng} / \mathrm{mL}$ & $\begin{array}{l}\text { Increased in acute stage; will help differentiate acute KD } \\
\text { from viral infections }\end{array}$ & $(16,17)$ \\
\hline Peripheral blood eosinophilia (PBE) & $0.0-6.0 \%$ & $\begin{array}{l}\text { Higher rates in acute stages of incomplete KD; may be } \\
\text { helpful in clinical setting of incomplete KD }\end{array}$ & $(18)$ \\
\hline
\end{tabular}


TABLE 2 | Immunological biomarkers of Kawasaki disease.

\begin{tabular}{|c|c|c|c|}
\hline Cellular markers & Biological functions & Comments & References \\
\hline CD8T cells & Cytotoxic T cell & $\begin{array}{l}\text { Decrease in acute KD; shown to sequester in inflamed } \\
\text { coronary arteries, functionally suppressed }\end{array}$ & $(21-23)$ \\
\hline Th1 cells & Regulate cellular immunity by secreting IL-2 and IFN- $\gamma$ & Downregulated in acute KD & $(24)$ \\
\hline Th2 cells & $\begin{array}{l}\text { Regulate humoral immunity by secreting IL-4, IL-5, IL-6 } \\
\text { and IL-10 }\end{array}$ & $\begin{array}{l}\text { Downregulated in acute KD and involved in response to } \\
\text { IVIG }\end{array}$ & $(21,24)$ \\
\hline CD14+ monocytes & Produce TNF $\alpha$, IL-6, IL-1 & Increased in acute stages and in association with CAAs & $(21)$ \\
\hline CD69+CD8T cells & Early activation marker for $\mathrm{T}$ cells & $\begin{array}{l}\text { Increased in acute KD; marker to determine disease } \\
\text { progression, treatment response, and convalescence in } \\
\text { acute KD }\end{array}$ & $(25)$ \\
\hline $\begin{array}{l}\text { Effector memory T-cells } \\
\text { (Tem) }\end{array}$ & $\begin{array}{l}\text { Found in the peripheral circulation and tissues; provide } \\
\text { the immune system with "memory" against previously } \\
\text { encountered pathogens. }\end{array}$ & Increase after IVIG treatment & $(25)$ \\
\hline Regulatory T cells (Treg) & Maintain tolerance to self-antigens & Decreased in acute KD, Increase after IVIG treatment & $(25,26)$ \\
\hline $\begin{array}{l}\text { Central memory T-cells } \\
(\text { Tcm) }\end{array}$ & $\begin{array}{l}\text { Found in the lymph nodes and in the peripheral } \\
\text { circulation, provide the immune system with "memory" } \\
\text { against previously encountered pathogens. }\end{array}$ & Increase in acute KD & $(25)$ \\
\hline $\begin{array}{l}\text { Myeloid and plasmocytoid } \\
\text { dendritic cells (DC }\end{array}$ & $\begin{array}{l}\text { Most potent antigen presenting cells that initiates } \\
\text { T-cell activation. }\end{array}$ & $\begin{array}{l}\mathrm{mDC} \text { increase in acute } \mathrm{KD} \\
\text { No increase in } \mathrm{pDC}\end{array}$ & $(20)$ \\
\hline Th17 proportions & Regulate inflammation by secreting IL-17 & Decreased in acute KD, Increase after IVIG treatment & $(27)$ \\
\hline IFN-Y and IL-2 & Th1 cytokine & Elevated in acute KD & (24) \\
\hline IL-4, IL-10 & Th2 cytokine & Elevated in acute KD & $(24)$ \\
\hline IL-6 & Important mediator of the acute phase response & $\begin{array}{l}\text { Upregulated in acute stages, more elevated in IVIG } \\
\text { refractory cases }\end{array}$ & $(24)$ \\
\hline IL-17A/F, ROR-gt & Induce IL-6 production & $\begin{array}{l}\text { Upregulated in acute stages; responsible for signs of } \\
\text { inflammation }\end{array}$ & (28) \\
\hline TGF-b & Marker of macrophage activation & Higher in acute stages, associated with CAAs & (29) \\
\hline TNFa & Mediate endothelial cell activation & Increase in acute $\mathrm{KD}$, role in CAAs & (30) \\
\hline CXCL10 (IP-10) & Th1 associated chemokine & Upregulated in acute KD & $(31,32)$ \\
\hline CCL-2 & Th2 associated chemokine & Activation in acute KD & $(31,32)$ \\
\hline
\end{tabular}

increased peripheral destruction in cases of acute KD. Furukawa et al. (22) studied CD14+ macrophages in KD patients and showed that they were higher in those with CAAs, thereby suggesting that absolute counts of CD14+ monocytes can be a marker of the severity of KD. These studies point toward a possible dysfunction in the innate immunity axis which could contribute to the inflammatory upregulation seen in acute stages of $\mathrm{KD}$.

\section{Acquired Immunity}

Studies have shown a decreased number of CD8 T cells during acute stages of KD (23). Immunohistochemistry studies in coronary arteries of KD patients at autopsy have shown that CD8 T cells preferentially sequester in the coronary arteries and are responsible for the inflammatory vasculitis $(24,26)$. Ehara et al. (27) showed that markers of early T cell activation [CD69(+)CD8T cells] increased in acute stages and can be used as a marker of disease progression and response to IVIg. Helper T cells (Th1 and Th2) have been shown to be upregulated during acute stages $(22,25)$. There is an apparent imbalance of $\mathrm{T}$ helper 17 cells (Th17) and regulatory $\mathrm{T}$ cells (Tregs) in acute KD. Th17 proportions have been shown to be upregulated while Treg proportions were found to be downregulated during the acute phase of KD (33).

\section{Soluble Markers}

Soluble markers of inflammation have been studied at great length in association with KD. Plasma levels of Th1 (IFNY, IL-12) and Th2 (IL-4, IL-13) cytokines have been shown to be elevated during acute stages of KD (34). Multiple pro-inflammatory and anti-inflammatory cytokines have been studied in acute stages of $\mathrm{KD}$, but none of these has been standardized as a biomarker of KD (29). Zhou et al. (28) showed a close relation between levels of vascular endothelial growth factor (VEGF), IL-6, and development of CAAs. TGF- $\beta$ signaling has been implicated in the development of coronary artery aneurysms (29). Th1-associated (CXCL10) and Th2associated chemokines (CCL2) are elevated in acute stages of $\mathrm{KD}$ and have been shown to decrease with IVIG $(35,36)$. Tumor Necrosis Factor $\alpha(\mathrm{TNF} \alpha)$ has a role in the recruitment of inflammatory cells to coronary endothelium and has been shown to have a role in the development of CAAs. TNF $\alpha$ blocking agents have been extensively studied as a therapy for KD (37).

\section{Summary}

Data on immunological markers in $\mathrm{KD}$ are derived from studies on relatively small groups of patients. The significance of these biomarkers in predicting the disease course, response to therapy 
and complications is not clear and needs confirmation across a different population.

\section{Proteomic Biomarkers (Table 3)}

Several proteins have been studied in KD.

\section{N-terminal Prohormone of Brain Natriuretic Peptide (NT-proBNP)}

NT-proBNP has been used as a marker of myocardial damage in KD. It is a marker of cardiomyocyte stress imposed by pressure or volume overload and is increased in response to cardiac dilatation and neuro-humoral factors. According to Dahdah et al.

TABLE 3 | Proteomic biomarkers of Kawasaki disease.

\begin{tabular}{|c|c|c|c|c|}
\hline Protein & Biological function & Caveats & Limitations & References \\
\hline NT-pro BNP & $\begin{array}{l}\text { Marker of myocardial damage; } \\
\text { increased in response to cardiac } \\
\text { dilatation and neuro-humoral } \\
\text { factors }\end{array}$ & $\begin{array}{l}\text { Higher values in CAAs and can } \\
\text { predict IVIG resistance }\end{array}$ & $\begin{array}{l}\text { Non-specific test } \\
\text { - Can be elevated in other } \\
\text { causes of diastolic } \\
\text { dysfunction } \\
\text { - Serum values vary with age }\end{array}$ & $(38-44)$ \\
\hline $\begin{array}{l}\text { Suppression of tumorigenicity } \\
\text { 2(sST2) }\end{array}$ & $\begin{array}{l}\text { Member of the IL } 1 \text { receptor } \\
\text { family and reflect cardiovascular } \\
\text { stress and fibrosis }\end{array}$ & $\begin{array}{l}\text { Elevated in acute stages of KD } \\
\text { Correlate with impaired } \\
\text { myocardial relaxation }\end{array}$ & $\begin{array}{l}\text { Prognostic significance of sST2 } \\
\text { levels in acute KD is unknown }\end{array}$ & $(45)$ \\
\hline Cardiac troponin I (cTnl)r & Marker of myocardial damage & Elevated in acute stages & Non-specific marker & $(46,47)$ \\
\hline Periostin & $\begin{array}{l}\text { Matricellular protein that plays a } \\
\text { role in vascular and cardiac } \\
\text { responses to injury }\end{array}$ & $\begin{array}{l}\text { Upregulated } 11 \text {-fold in acute } \\
\text { and chronic KD coronary } \\
\text { arteries }\end{array}$ & Non-specific & $(48)$ \\
\hline $\begin{array}{l}\text { Gamma-glutamyl transferase(GGT) } \\
\text { and Alanine transferase (ALT) }\end{array}$ & $\begin{array}{l}\text { Biomarkers of cardiocyte } \\
\text { inflammation }\end{array}$ & $\begin{array}{l}\text { Increased in acute stages of } \\
\mathrm{KD}\end{array}$ & Non-specific & $(45)$ \\
\hline Clusterin & $\begin{array}{l}\text { Component of high density } \\
\text { lipoproteins; role in maintaining } \\
\text { integrity of coronary endothelium }\end{array}$ & $\begin{array}{l}\text { Values }<12 \mathrm{mg} / \mathrm{L} \text { associated } \\
\text { with CAAs occurrence in } \mathrm{KD} \\
\text { patients }\end{array}$ & $\begin{array}{l}\text { Need validation via larger } \\
\text { studies }\end{array}$ & (49) \\
\hline $\begin{array}{l}\text { Thrombospondin (TSP-1 and } \\
\text { TSP-2) }\end{array}$ & $\begin{array}{l}\text { Involved in cardiovascular } \\
\text { inflammation and maintaining the } \\
\text { integrity and function of cardiac } \\
\text { structures }\end{array}$ & $\begin{array}{l}\text { - Elevated in acute KD } \\
\text { - Associated with high risk of } \\
\text { IVlg resistance }\end{array}$ & $\begin{array}{l}\text { Need larger studies for } \\
\text { validation }\end{array}$ & $(50)$ \\
\hline $\begin{array}{l}\text { Fibrinogen beta and gamma } \\
\text { chains }\end{array}$ & $\begin{array}{l}\text { Cleavage products of fibrinogen } \\
\text { and fibrin regulate systemic } \\
\text { inflammation }\end{array}$ & Elevated in acute KD & $\begin{array}{l}\text { Non-specific markers of } \\
\text { inflammation }\end{array}$ & $(49)$ \\
\hline CD5 antigen-like precursor (CD5L) & Marker of acute inflammation & Increased in acute KD & $\begin{array}{l}\text { Non-specific markers of } \\
\text { inflammation }\end{array}$ & (49) \\
\hline Nitric oxide synthases (iNOS) & $\begin{array}{l}\text { NO has an important role in } \\
\text { maintaining vascular tone and } \\
\text { integrity of vessels }\end{array}$ & $\begin{array}{l}\text { Correlate with the severity and } \\
\text { progression of CAA }\end{array}$ & $\begin{array}{l}\text { Non-specific marker of } \\
\text { inflammation }\end{array}$ & $(51)$ \\
\hline Periostin & $\begin{array}{l}\text { Matricellular protein of coronary } \\
\text { endothelium }\end{array}$ & $\begin{array}{l}\text { KD patients have significantly } \\
\text { elevated serum values } \\
\text { compared with febrile controls }\end{array}$ & $\begin{array}{l}\text { Tissue based tests are difficult } \\
\text { in clinical settings }\end{array}$ & $(44)$ \\
\hline $\begin{array}{l}\text { Lipopolysaccharide-binding } \\
\text { protein (LBP) }\end{array}$ & Markers of inflammation & Higher in acute KD & $\begin{array}{l}\text { Need validation in larger } \\
\text { studies }\end{array}$ & $(52)$ \\
\hline $\begin{array}{l}\text { Leucine-rich alpha-2-glycoprotein } \\
\text { (LRG1) }\end{array}$ & Markers of inflammation & Higher in acute KD & $\begin{array}{l}\text { Need validation in larger } \\
\text { studies }\end{array}$ & $(52)$ \\
\hline Angiotensinogen (AGT) & Markers of inflammation & Higher in acute KD & $\begin{array}{l}\text { Need validation in larger } \\
\text { studies }\end{array}$ & $(52)$ \\
\hline Tenacin- C & $\begin{array}{l}\text { Extracellular matrix glycoprotein } \\
\text { that is upregulated at sites of } \\
\text { tissue injury and inflammation }\end{array}$ & $\begin{array}{l}\text { Useful biomarker to predict the } \\
\text { risk of developing CAAs and } \\
\text { IVIg resistance }\end{array}$ & $\begin{array}{l}\text { Need validation in larger } \\
\text { studies }\end{array}$ & (53) \\
\hline $\begin{array}{l}\text { Urine protein markers: } \\
\text { - Filamin } \\
\text { - Talin } \\
\text { - Complement regulator CSMD3 } \\
\text { - Immune pattern recognition } \\
\text { receptor muclin } \\
\text { - Immune cytokine protease } \\
\text { meprin A }\end{array}$ & Markers of inflammation & $\begin{array}{l}\text { - Higher in acute KD } \\
\text { - Non-invasive biomarkers } \\
\text { of KD }\end{array}$ & $\begin{array}{l}\text { Need validations via larger } \\
\text { studies }\end{array}$ & (54) \\
\hline
\end{tabular}


(31), myocardial involvement in acute KD is universal from the histological and functional perspectives and hence the role of NTproBNP as a potential biomarker has been extensively studied. The interpretation of serum NT-proBNP levels in children is difficult because these are age-dependent, being highest in infancy and decreasing thereafter. The sensitivity and specificity of cut-off values as a biomarker for KD are derived from receiver operating characteristics (ROC) analysis, the upper normal limit for age, and Z-scores for age. Shiraishi et al. (32) showed that the sensitivity and specificity of diagnosing acute KD were 97.8 and $47 \%$, respectively, at a $z$ score $>2$. A meta-analysis on NTproBNP in KD has substantiated its use as a diagnostic marker and cut-off values between 96 and $260 \mathrm{pg} / \mathrm{ml}$ have been shown to have sensitivity between 66 and 98\% in identifying cases of $\mathrm{KD}$ (30). NT-proBNP levels are higher in patients with CAAs (values $515-1,300 \mathrm{pg} / \mathrm{ml}$ have a sensitivity and specificity of 73-95 and $61-85 \%$, respectively) (38) and can predict IVIG resistance. A value between 629 and $1,300 \mathrm{pg} / \mathrm{ml}$ has a high sensitivity (70$79 \%)$ as well as specificity $(58-77 \%)$ for diagnosis of $\operatorname{KD}(39,40)$. From our center, we have reported a cut-off at $1,025 \mathrm{pg} / \mathrm{mL}$ for NT-proBNP levels which has a sensitivity of $88 \%$ and specificity of $96 \%$ (41) in the acute phase of KD.

\section{Other Cardiovascular Biomarkers}

Suppression of tumorigenicity-2 (sST2) is a member of the interleukin 1 (IL-1) receptor family and reflects cardiovascular stress and fibrosis. It is elevated in acute stages of KD and the levels correlate with impaired myocardial relaxation. However, the prognostic significance in acute KD is unclear (42).

Kim et al. (43) have described cardiac troponin I (cTnI) in relation with $\mathrm{KD}$ and showed a significant increase in the level of cTnI in the acute stage of KD. Periostin is a matricellular protein that mediates responses associated with cardiovascular injury. Reindel et al. (44) have shown that periostin gets upregulated in coronary arteries during the acute and chronic phases of $\mathrm{KD}$ when compared to other febrile controls. Gamma-glutamyl transferase (GGT) and alanine transferase (ALT) have also been studied as biomarkers of cardiac inflammation. However, these are rather nonspecific and are not a reliable marker for KD perse (42).

\section{Thrombospondin (TSP-1 and TSP-2)}

TSP-1 and TSP-2 are proteins involved in cardiovascular inflammation and maintaining the integrity and function of cardiac structures. These have been shown to be elevated in the acute phase of $\mathrm{KD}$ in comparison with other febrile controls and higher values are seen in those with IVIg resistance. With a cutoff value of $31.50 \mathrm{ng} / \mathrm{mL}$, the sensitivity of TSP-2 has been shown to be $82.35 \%$ and specificity $64.81 \%$ in predicting IVIG resistance in acute $\mathrm{KD}(45)$.

\section{Other Proteins}

Clusterin is a part of the high-density lipoproteins (HDL) and has a role in many physiologic processes including maintaining the integrity of coronary artery walls. Plasma clusterin levels have been studied in KD and values lower than $12 \mathrm{mg} / \mathrm{L}$ have been associated with the occurrence of CAAs in KD patients (46). Yu et al. $(46,55)$ have studied several proteins of fibrinogen cascade in $\mathrm{KD}$. It was found that these were increased in patients with $\mathrm{KD}$ and may serve as a good biomarker of KD. The expression of nitric oxide synthases (iNOS) has been shown to correlate with the extent of coronary damage and progression of CAAs in patients with acute KD (47). Tenascin- C (TN-C) is a marker of tissue injury and inflammation and has a role in the maintenance of the extracellular matrix of cardiac tissue. Okuma et al. (48) have studied serum TN-C level in association with the risk of developing CAAs and resistance to IVIg therapy in the acute phase of KD.

\section{Summary}

Several protein biomarkers have been studied in relation to $\mathrm{KD}$ but most of these studies are based in small cohorts of patients at a single center. NT-proBNP is widely believed to be a useful marker for confirmation of the diagnosis of KD at the bedside. The levels of NT-proBNP in KD, however, may overlap those in other febrile illnesses with cardiac dysfunction. Other biomarkers are still in their early stages of discovery and will require validation in larger populations before the results can be used in clinical settings.

\section{Urine Biomarkers}

Kentsis et al. (49) studied urine protein biomarkers in relation with $\mathrm{KD}$ and showed an abundance of markers of tissue injury (filamin and talin), complement regulator (CSMD3), cytokine protease (meprin A), and immune pattern recognition receptor (muclin) in the urine of affected patients. However, these results need replication in larger studies before these can be used as noninvasive biomarkers in KD.

\section{GENETIC STUDIES IN KD (TABLE 4)}

A genetic basis of $\mathrm{KD}$ has been strongly considered taking into account the geographical differences in the incidence and high risk of occurrence in family members. Incidence of KD in Japan, Korea and Taiwan is more than 10 times the incidence in Western countries (50-53). This difference is a pointer toward a possible genetic susceptibility or may reflect environmental or lifestyle differences amongst these populations. A higher incidence is also known amongst Japanese Americans settled in Hawaii and this is comparable with the incidence in Japan, further pointing toward a possible genetic association of the disease (75). Studies have shown that the risk of developing $\mathrm{KD}$ in siblings of a KD patient is 10-30-fold higher as compared to the general population (76). Two types of approaches have been utilized for studying the genetic basis of KD:

1. Candidate gene approach

2. Genome-wide approach

\section{Candidate Gene Approach}

Candidate gene studies are the well-known approach to study genes associated with $\mathrm{KD}$ based on their function in the pathophysiology of the disease. 
TABLE 4 | Genetic biomarkers of Kawasaki disease.

\begin{tabular}{|c|c|c|c|c|c|c|c|}
\hline Gene & Biological function & Study & $\begin{array}{l}\text { Year } \\
\text { and country }\end{array}$ & Ethnicity & Polymorphism & Conclusion & References \\
\hline \multirow[t]{3}{*}{ ITPKC } & $\begin{array}{l}\text { Calcium channel modulator and } \\
\text { regulates calcium release from } \mathrm{ER} \text {, } \\
\text { Acts as negative regulator of } \mathrm{T} \\
\text { cell activation }\end{array}$ & Wang et al. & 2014, China & Asian & rs2720378, rs2069762 & Higher risk of developing KD & $(56)$ \\
\hline & & Peng et al. & 2012, China & Asian & rs2290692 & Higher risk of developing KD & $(57)$ \\
\hline & & Kou et al. & 2011, Taiwan & Asian & rs28493229 & $\begin{array}{l}\text { Higher risk of developing KD } \\
\text { and higher risk of CAAs }\end{array}$ & $(58)$ \\
\hline ORAl1 & $\begin{array}{l}\text { Involved in calcium influx into T-cells } \\
\text { and activation of the Ca2+/NFAT } \\
\text { pathway, regulates immune system } \\
\text { and inflammatory responses }\end{array}$ & Onouchi et al. & 2016, Japan & Asian & rs3741596 & Higher risk of developing KD & (59) \\
\hline \multirow[t]{3}{*}{ CD40 } & $\begin{array}{l}\text { Activates immune system and is } \\
\text { involved in immune and } \\
\text { inflammatory responses }\end{array}$ & Lou et al. & 2016, Japan & Asian & $\begin{array}{l}\text { rs2736340, } \\
\text { rs4813003, rs3818298 }\end{array}$ & Higher risk of developing KD & $(60)$ \\
\hline & & Cheng et al. & 2015, China & Asian & rs1801274 & Higher risk of developing KD & $(61)$ \\
\hline & & Onouchi et al. & 2012, Japan & Asian & rs1535045, rs4813003 & Higher risk of developing KD & $(62)$ \\
\hline \multirow[t]{3}{*}{ BLK } & $\begin{array}{l}\text { Involved in signal transduction and } \\
\text { phosphorylation of ITAM residues of } \\
\text { Iga and Igb, Responsible for B } \\
\text { cell activation }\end{array}$ & Lou et al. & 2015, China & Asian & rs2736340 & Higher risk of developing KD & $(60)$ \\
\hline & & Chang et al. & 2013, Taiwan & Asian & rs2736340 & Higher risk of developing KD & $(63)$ \\
\hline & & Lee et al. & 2012, Taiwan & Asian & rs2618476, rs2736340 & Higher risk of developing KD & $(64)$ \\
\hline \multirow[t]{3}{*}{ FCGR2A } & $\begin{array}{l}\text { Involved in metabolism and turnover } \\
\text { of circulating lgG, Required for } \\
\text { phagocytosis and clearing of } \\
\text { immune complexes }\end{array}$ & Duan et al. & 2014, China & Asian & rs1801274 & Higher risk of developing KD & $(65)$ \\
\hline & & Khor et al. & 2013, Singapore & Mixed & rs1801274 & Higher risk of developing KD & $(66)$ \\
\hline & & Yan et al. & 2013, China & Asian & rs1801274 & $\begin{array}{l}\text { Higher risk of developing } \\
\text { CAAs in KD }\end{array}$ & $(67)$ \\
\hline \multirow[t]{3}{*}{ CASP3 } & $\begin{array}{l}\text { Involved in cell apoptosis, regulates } \\
\text { cellular processes in T cells }\end{array}$ & Wang et al. & 2014, China & Asian & rs2069762, rs2720378 & Higher risk of developing KD & $(68)$ \\
\hline & & Onouchi et al. & 2010, Japan & Asian & rs72689236 & Higher risk of developing KD & (69) \\
\hline & & Kou et al. & 2011, Taiwan & Asian & rs72689236 & Higher risk of developing KD & $(70)$ \\
\hline TGF $\beta$ R2 & Regulation of gene transcription & Choi et al. & 2012, Korea & Asian & & Higher risk of developing KD & $(71)$ \\
\hline \multirow[t]{2}{*}{ SMAD3 } & $\begin{array}{l}\text { Signal transducer and transcriptional } \\
\text { modulator, involved in } \\
\text { down-regulation of T-cells and } \\
\text { cardiovascular remodeling }\end{array}$ & Kuo et al. & 2011, Taiwan & Asian & rs1438386 & $\begin{array}{l}\text { Higher risk of developing } \\
\mathrm{KD} \text {, but not to CAAs }\end{array}$ & $(72)$ \\
\hline & & Peng et al. & 2016, China & Asian & rs1438386 & Higher risk of developing KD & (73) \\
\hline ADAM17 & $\begin{array}{l}\text { Required for activation of notch } \\
\text { signaling pathway and processing }\end{array}$ & Peng et al. & 2016, China & Asian & rs6705408 & $\begin{array}{l}\text { Higher risk of developing KD } \\
\text { and development of CAAs }\end{array}$ & (73) \\
\hline MMP-11 & $\begin{array}{l}\text { Causes breakdown of extracellular } \\
\text { matrix }\end{array}$ & Ban et al. & 2010 Korea & Asian & rs738792 & Higher risk of developing KD & $(74)$ \\
\hline
\end{tabular}

\section{HLA Genes}

Early genetic studies on KD were focused on HLA alleles. HLA class 1 antigens have been studied in great detail in various populations $(54,77)$. Significant predominant association of HLA-Bw54 has been found in Japanese KD population while single nucleotide polymorphisms (SNP) located in the HLA-E gene was suggested to be associated with KD in the Han Chinese population (77). A positive association was found between HLABw51 and KD in the White and Jewish population while HLABw51 was reported to be negatively associated in the Korean population. In a recent GWAS, association with HLA class II antigens peaked at the intergenic region between HLA-DQB2 and HLA-DOB (78). SNPs in HLA class III region have also been described in association with KD (79). TNF $\infty$ expression has been shown to be elevated in association with CAAs in KD in Korean, Taiwanese, Chinese and Caucasian populations, but these results could not be replicated in studies from Japan (80).

\section{Non-HLA Genes}

Burns et al. (78) found an SNP in the promoter region of the IL-4 gene to be asymmetrically transmitted in children with $\mathrm{KD}$. MHC-class-I-chain-related gene A (MICA) alleles were reported as biomarkers for evaluation of coronary aneurysms in $\mathrm{KD}$. 
Lower frequency of MICA allele 276 A4 was reported in KD patients with aneurysms (81).

\section{Genome-Wide Approach}

\section{Genome-Wide Linkage Analyses (GWLS)}

GWLS were used to map the genetic loci of diseases by analyses of related individuals through the logarithm of odds (LOD) score. The first GWLS on KD was done by Onouchi et al. (82) who studied 79 families of children with KD and analyzed 75 sibling pairs. They identified 10 chromosomal loci with positive linkage, among which the $12 \mathrm{q} 24$ region showed the most significant evidence of linkage. GWLS studies identified Inositol 1,4,5trisphosphate 3-kinase C (ITPKC) gene in association with risk of $\mathrm{KD}(83)$.

\section{Genome-Wide Association Studies (GWAS)}

GWAS are based on the analysis of a genome-wide set of genetic variants typically SNP in affected individuals and healthy controls to see if a variant is repeatedly associated with a disease. GWAS studies on KD have identified several genes in association with the disease. The significant susceptibility genes identified include caspase-3 (CASP3) (69), calcium releaseactivated calcium modulator 1 (ORAI1) (59), ATP-binding cassette sub-family C member 4 gene(ABCC4) (84), Fc Fragment of IgG Receptor IIa (FCGR2A) (66), Transforming growth factor $\beta$ pathway (TGFB2, TGFBR2, and SMAD3) (85), B lymphocyte kinase (BLK) (63), matrix metalloproteinase 11 (MMP-11) (74), and CD40 (86).

\section{Genes Associated With B-Cell Signaling CD40}

CD40L-CD40 interaction is known in relation to triggering and progression of acute coronary syndromes (87). Higher CD40 ligand expression on CD4 T-cells of KD patients as compared to febrile controls has been reported by a previous study. This over-expression decreased after IVIg administration (88). SNPs around $\mathrm{CD} 40$ showed association with $\mathrm{KD}$ susceptibility in Japanese (rs4813003, located $4.9 \mathrm{~Kb}$ downstream) and Taiwanese (rs1569723, located $4.8 \mathrm{~Kb}$ upstream) population. GWAS from Taiwan and Japan have also shown the association of SNPs of BLK and $C D 40$ in the pathogenesis of $\mathrm{KD}(66)$.

\section{B Lymphoid Tyrosine Kinase (BLK)}

BLK has a role in signal transduction of B cells (64). GWAS from Taiwan and Japan have shown the association of SNPs of $B L K$ and CD40 in the pathogenesis of KD (68). Kawasaki Disease Genetics Consortium (2013) confirmed the association of BLK with KD susceptibility in Korean and European population (89).

\section{Fc Fragment of IgG Receptor Ila (FCGR2A)}

FCGR2A is present on Fc region of IgG and encodes for cell surface receptor protein on phagocytic cells. GWAS done in five independent centers have confirmed the association of FCGR2A with KD susceptibility (66). Associations of SNPs rs2736340, rs4813003, rs3818298, and rs1801274 with KD were reported in a Han Chinese population $(60,66)$.

\section{T-Cell Activation Genes} Inositol 1,4,5-Trisphosphate 3-kinase (ITPK) Enzyme Gene

ITPKC is involved in $\mathrm{Ca}^{2+} /$ NFAT pathway and acts as a potential candidate for immune activation and T-cell receptor signaling $(68,83)$. Association of functional SNP (rs28493229) in ITPKC with development of $\mathrm{KD}$ and CAA risk was first reported in Japanese and American children (83). However, no significant association was found between rs28493229 and KD risk in Taiwanese patients (90). Significant associations of C-allele of rs28493229 with KD and BCG scar reactivation in the acute stage were reported by Lin et al. (56).

\section{Calcium Release-Activated Calcium Channel Protein 1 (ORAl1)}

ORAI1 is a $\mathrm{Ca}^{2+}$ channel protein involved in $\mathrm{T}$ cell regulation and inflammatory responses. Onouchi et al. (59) showed a significant non-synonymous association of SNP (rs3741596) in exon 2 of the ORAI1 gene with a high risk of KD in Japan. Another study reported a rare variant (rs141919534) in association with KD (91).

\section{Genes Associated With the Apoptotic Pathway \\ Caspase 3 (CASP3)}

CASP3 gene is an execution-phase caspase involved in apoptosis of immune cells. Various SNPs including rs2720378, rs72689236, and rs113420705 have been reported in association with KD (69). Kuo et al. found that SNP rs28493229 (ITPKC) and rs113420705 (CASP3) showed an increased risk of IVIG resistance and development of CAAs in Japanese but not in Taiwanese population (92).

\section{TGF- $\beta$ Signaling Pathway}

The TGF- $\beta$ pathway is an essential component of inflammation, T-cell activation and tissue remodeling. Genetic variations in $T G F-\beta 2, T G F-\beta R 2$, and SMAD3 are associated with CAA formation and was confirmed in replication studies (85). SNPrs6550004 in TGF-BR2 and rs1495592 in SMAD5 showed significant associations with KD in the Korean population (93).

\section{Gene Expression Studies}

MicroRNAs (miRNAs) are 20-26 nucleotides long non-coding single-stranded RNA segments that modify post-transcriptional mRNA gene expression. Shimizu et al. (94) showed 6 miRNAs (miR-143, miR-199b-5p, miR-618, miR-223, miR-145, and miR-145) that were differentially expressed in acute KD. In another study, miRNA-200c and miRNA-371-5p have also been studied as diagnostic biomarkers of KD (54). miR-27b suppresses endothelial cell proliferation and has been studied as a therapeutic target in patients of acute $\mathrm{KD}$ (95).

- In a recent multicenter study by Wright et al. (96), the use of whole-blood gene expression patterns was explored and a 13transcript blood gene expression signature has been developed to distinguish $\mathrm{KD}$ from other infectious and inflammatory febrile illnesses in the first week of illness. 
- Whole genome sequencing in a family with KD has also shown genetic variations in the toll-like receptor-6 (TLR6) gene in their two affected children (97).

Summary: Most of the genetic studies have been carried out in small cohorts of patients with $\mathrm{KD}$ and the results are not reproducible across different populations and ethnicities. These studies require validations in larger and multinational cohorts with additional case-control sets for a better understanding of the genetic profiles.

\section{CONCLUSIONS}

The need for a robust set of biochemical biomarkers to validate the diagnosis of $\mathrm{KD}$ in the clinical setting has become the need of the hour. Clinical application of these biomarkers is limited. Inflammatory parameters can, at best, facilitate confirmation of a clinical diagnosis of $\mathrm{KD}$ but none of these is pathognomonic of $\mathrm{KD}$. Further, these markers have very low specificity for the diagnosis of $\mathrm{KD}$. The newer proteomic studies

\section{REFERENCES}

1. Kawasaki T, Kosaki F, Okawa S, Shigematsu I, Yanagawa H. A new infantile acute febrile mucocutaneous lymph node syndrome (MLNS) prevailing in Japan. Pediatrics. (1974) 54:271-6.

2. Lin M-T, Wu M-H. The global epidemiology of Kawasaki disease: review and future perspectives. Glob Cardiol Sci Pract. (2017) 2017:e201720. doi: 10.21542 /gcsp. 2017.20

3. Singh S, Bansal A, Gupta A, Kumar RM, Mittal BR. Kawasaki disease: a decade of experience from North India. Int Heart J. (2005) 46:679-89. doi: $10.1536 /$ ihj. 46.679

4. Khubchandani RP, Khemani C. Kawasaki disease registries reap results experience in Mumbai. Indian J Pediatr. (2006) 73:545-6. doi: 10.1007/BF02759910

5. Paul DK, Gupta A, Lahiri M. Kawasaki disease in Calcutta. Indian Pediatr. (2000) 37:1264-5.

6. Narayanan SN, Krishnaveni null, Sabarinathan K. Kawasaki disease. Indian Pediatr. (1997) 34:139-43.

7. Suresh N, Varadarajan VV, Ranjith MS. Kawasaki disease in south India: a prospective, case-control study. Ann Trop Paediatr. (2007) 27:277-83. doi: 10.1179/146532807X245661

8. Singh S, Jindal AK, Pilania RK. Diagnosis of Kawasaki disease. Int J Rheum Dis. (2018) 21:36-44. doi: 10.1111/1756-185X.13224

9. Rahbari-Manesh AA, Salamati P, Ghaforian S, Zekavat M. Relationship between ESR, CRP, platelet count and coronary artery disease in Kawasaki disease. Iran J Pediatr. (2005) 15:139-44. Available online at: https://www.sid.ir/en/journal/ViewPaper.aspx?id=38243

10. Huang M-Y, Gupta-Malhotra M, Huang J-J, Syu F-K, Huang T-Y. Acute-phase reactants and a supplemental diagnostic aid for Kawasaki disease. Pediatr Cardiol. (2010) 31:1209-13. doi: 10.1007/s00246-010-9801-y

11. Tremoulet AH, Jain S, Chandrasekar D, Sun X, Sato Y, Burns JC. Evolution of laboratory values in patients with Kawasaki disease. Pediatr Infect Dis J. (2011) 30:1022-6. doi: 10.1097/INF.0b013e31822d4f56

12. Koyanagi H, Yanagawa H, Nakamura Y, Yashiro M. Leukocyte counts in patients with Kawasaki disease: from the results of nationwide surveys of Kawasaki disease in Japan. Acta Paediatr. (1997) 86:1328-32. doi: 10.1111/j.1651-2227.1997.tb14907.x

13. Dominguez SR, Martin B, Heizer H, Jone P-N, Tong S, Davidson J, et al. Procalcitonin (PCT) and Kawasaki disease: does PCT correlate with IVIGresistant disease, admission to the intensive care unit, or development of coronary artery lesions? J Pediatr Infect Dis Soc. (2016) 5:297-302. doi: $10.1093 /$ jpids/piv019 have identified some biomarkers in association with $\mathrm{KD}$ but these also need validation across different populations before these can be used for confirming a diagnosis of KD. Genomewide studies, linkage studies and miRNA-based biomarkers are still in their early stage of development and fall short of being a diagnostic test for this enigmatic condition. These genetic markers are pointers toward a diagnostic panel for KD but clearly, these are early days and much more work needs to be done before a robust laboratory diagnostic test can be established.

\section{AUTHOR CONTRIBUTIONS}

HC, JN, RK: Literature review, interpretation of data and draft of the manuscript. VP: critical review and editing of the manuscript. DS: critical review of studies cited in the manuscript, editing of manuscript. AR: concept and design of the manuscript, critical review of studies cited in the manuscript, editing of manuscript. SS: concept and design of the manuscript, critical review, and editing of the manuscript.

14. Kuo H-C, Liang C-D, Wang C-L, Yu H-R, Hwang K-P, Yang KD. Serum albumin level predicts initial intravenous immunoglobulin treatment failure in Kawasaki disease. Acta Paediatr. (2010) 99:1578-83. doi: 10.1111/j.1651-2227.2010.01875.x

15. Roy S, Majumdar SD, Chakrabartty S, Chakravarti S. Mean platelet volume as a marker of Kawasaki disease in children. Indian J Child Health. (2017) 318-21. Available online at: https://www.researchgate.net/profile/Soumya Roy11/publication/318392865_Mean_platelet_volume_as_a_marker_of_ Kawasaki_disease_in_children/links/5966fb9da6fdcc18ea60a96e/Meanplatelet-volume-as-a-marker-of-Kawasaki-disease-in-children.pdf

16. Lee $\mathrm{NH}$, Choi HJ, Kim YH. Clinical usefulness of serum procalcitonin level in distinguishing between Kawasaki disease and other infections in febrile children. Korean J Pediatr. (2017) 60:112-7. doi: 10.3345/kjp.2017. 60.4 .112

17. Öner T, Yilmazer MM, Güven B, Devrim I, Cilengiroglu ÖV, Demirpençe $\mathrm{S}$, et al. An observational study on peripheral blood eosinophilia in incomplete Kawasaki disease. Anatol J Cardiol. (2012) 12:160-4. doi: $10.5152 / \mathrm{akd} .2012 .042$

18. Xiu-Yu S, Jia-Yu H, Qiang H, Shu-Hui D. Platelet count and erythrocyte sedimentation rate are good predictors of Kawasaki disease: ROC analysis. $J$ Clin Lab Anal. (2010) 24:385-8. doi: 10.1002/jcla.20414

19. Liu R, Gao F, Huo J, Yi Q. Study on the relationship between mean platelet volume and platelet distribution width with coronary artery lesion in children with Kawasaki disease. Platelets. (2012) 23:11-6. doi: 10.3109/09537104.2011.586073

20. Jin J, Wang J, Lu Y, Fan Z, Huang N, Ma L, et al. Platelet-derived microparticles: a new index of monitoring platelet activation and inflammation in Kawasaki disease. Indian J Pediatr. (2018) 86:250-55. doi: $10.1007 /$ s12098-018-2765-2

21. Tomoyuki Takahashi SK. Circulating myeloid dendritic cells is decreased in the acute phase of kawasaki disease. J Clin Exp Cardiol. (2013) 4:272. doi: 10.4172/2155-9880.1000272

22. Furukawa S, Matsubara T, Yabuta K. Mononuclear cell subsets and coronary artery lesions in Kawasaki disease. Arch Dis Child. (1992) 67:706-8. doi: 10.1136/adc.67.6.706

23. Brogan PA, Shah V, Clarke LA, Dillon MJ, Klein N. T cell activation profiles in Kawasaki syndrome. Clin Exp Immunol. (2008) 151:267-74. doi: 10.1111/j.1365-2249.2007.03567.x

24. Rivas MN, Lee Y, Wakita D, Chiba N, Dagvadorj J, Shimada K, et al. CD8+ T cells contribute to the development of coronary arteritis in the Lactobacillus casei extract-induced murine model of Kawasaki disease. Arthritis Rheumatol. (2017) 69:410-21. doi: 10.1002/art.39939 
25. Wang Y, Wang W, Gong F, Fu S, Zhang Q, Hu J, et al. Evaluation of intravenous immunoglobulin resistance and coronary artery lesions in relation to Th1/Th2 cytokine profiles in patients with Kawasaki disease. Arthritis Rheum. (2013) 65:805-14. doi: 10.1002/art.37815

26. Brown TJ, Crawford SE, Cornwall ML, Garcia F, Shulman ST, Rowley AH. CD8 T lymphocytes and macrophages infiltrate coronary artery aneurysms in acute Kawasaki disease. J Infect Dis. (2001) 184:940-3. doi: 10.1086/323155

27. Ehara H, Kiyohara K, Izumisawa Y, Ito T. Early activation does not translate into effector differentiation of peripheral CD8T cells during the acute phase of Kawasaki disease. Cell Immunol. (2010) 265:57-64. doi: 10.1016/j.cellimm.2010.07.003

28. Zhou Y, Wang S, Zhao J, Fang P. Correlations of complication with coronary arterial lesion with VEGF, PLT, D-dimer and inflammatory factor in child patients with Kawasaki disease. Eur Rev Med Pharmacol Sci. (2018) 22:5121-6. doi: 10.26355/eurrev_201808_15706

29. Sohn MH, Noh SY, Chang W, Shin KM, Kim DS. Circulating interleukin 17 is increased in the acute stage of Kawasaki disease. Scand J Rheumatol. (2003) 32:364-6. doi: 10.1080/03009740410005034

30. Lin K-H, Chang S-S, Yu C-W, Lin S-C, Liu S-C, Chao H, et al. Usefulness of natriuretic peptide for the diagnosis of Kawasaki disease: a systematic review and meta-analysis. BMJ Open. (2015) 5:6703. doi: 10.1136/bmjopen-2014-006703

31. Dionne A, Dahdah N. A decade of NT-proBNP in acute Kawasaki disease, from physiological response to clinical relevance. Children. (2018) 5:141. doi: 10.3390/children5100141

32. Shiraishi M, Fuse S, Mori T, Doyama A, Honjyo S, Hoshino Y, et al. N-terminal pro-brain natriuretic Peptide as a useful diagnostic marker of acute Kawasaki disease in children. Circ J. (2013) 77:2097-101. doi: 10.1253/circj.CJ-12-1281

33. Jia S, Li C, Wang G, Yang J, Zu Y. The T helper type $17 /$ regulatory T cell imbalance in patients with acute Kawasaki disease. Clin Exp Immunol. (2010) 162:131-7. doi: 10.1111/j.1365-2249.2010.04236.x

34. Kimura J, Takada H, Nomura A, Ohno T, Mizuno Y, Saito M, et al. Th1 and Th2 cytokine production is suppressed at the level of transcriptional regulation in Kawasaki disease. Clin Exp Immunol. (2004) 137:444-9. doi: 10.1111/j.1365-2249.2004.02506.x

35. Ko T-M, Kuo H-C, Chang J-S, Chen S-P, Liu Y-M, Chen H-W, et al. CXCL10/IP-10 is a biomarker and mediator for Kawasaki disease. Circ Res. (2015) 116:876-83. doi: 10.1161/CIRCRESAHA.116.305834

36. Shikishima Y, Saeki T, Matsuura N. Chemokines in Kawasaki disease: measurement of CCL2, CCL22 and CXCL10. Asian Pac J Allergy Immunol. (2003) 21:139-43.

37. Hui-Yuen JS, Duong TT, Yeung RSM. TNF- $\alpha$ is necessary for induction of coronary artery inflammation and aneurysm formation in an animal model of Kawasaki disease. J Immunol. (2006) 176:6294-301. doi: 10.4049/jimmunol.176.10.6294

38. Kaneko K, Yoshimura K, Tsuji S. Brain natriuretic peptide as a novel diagnostic biomarker in Kawasaki disease. J Compr Pediatr. (2014) 5:19505. doi: 10.17795/compreped-19505

39. Kim SY, Han MY, Cha S-H, Jeon YB. N-terminal pro-brain natriuretic peptide (NT proBNP) as a predictive indicator of initial intravenous immunoglobulin treatment failure in children with Kawasaki disease: a retrospective study. Pediatr Cardiol. (2013) 34:1837-43. doi: 10.1007/s00246-013-0724-2

40. Kim MK, Song MS, Kim GB. Factors predicting resistance to intravenous immunoglobulin treatment and coronary artery lesion in patients with Kawasaki disease: analysis of the Korean nationwide multicenter survey from 2012 to 2014. Korean Circ J. (2018) 48:71-9. doi: 10.4070/kcj.2017.0136

41. Reddy M, Singh S, Rawat A, Sharma A, Suri D, Rohit MK. Pro-brain natriuretic peptide (ProBNP) levels in North Indian children with Kawasaki disease. Rheumatol Int. (2016) 36:551-9. doi: 10.1007/s00296-016-3430-6

42. Sato YZ, Molkara DP, Daniels LB, Tremoulet AH, Shimizu C, Kanegaye JT, et al. Cardiovascular biomarkers in acute Kawasaki disease. Int J Cardiol. (2013) 164:58-63. doi: 10.1016/j.ijcard.2011.06.065

43. Kim M, Kim K. Elevation of cardiac troponin I in the acute stage of Kawasaki disease. Pediatr Cardiol. (1999) 20:184-8. doi: 10.1007/s002469900437

44. Reindel R, Kim K-YA, Baker SC, Shulman ST, Perlman EJ, Lingen MW, et al. Periostin is upregulated in coronary arteriopathy in Kawasaki disease and is a potential diagnostic biomarker. Pediatr Infect Dis J. (2014) 33:659-61. doi: 10.1097/INF.0000000000000233
45. Yang S, Song R, Li X, Zhang T, Fu J, Cui X. Thrombospondin2 predicts response to treatment with intravenous immunoglobulin in children with Kawasaki disease. BMJ Paediatr Open. (2018) 2:e000190. doi: 10.1136/bmjpo-2017-000190

46. Yu H-R, Kuo H-C, Huang E-Y, Liang C-D, Hwang K-P, Lin I-C, et al. Plasma clusterin levels in predicting the occurrence of coronary artery lesions in patients with Kawasaki disease. Pediatr Cardiol. (2010) 31:1151-6. doi: 10.1007/s00246-010-9769-7

47. Yu X, Hirono K-I, Ichida F, Uese K-I, Rui C, Watanabe S, et al. Enhanced iNOS expression in leukocytes and circulating endothelial cells is associated with the progression of coronary artery lesions in acute Kawasaki disease. Pediatr Res. (2004) 55:688-94. doi: 10.1203/01.PDR.0000113464.93042.A4

48. Yokouchi Y, Oharaseki T, Enomoto Y, Sato W, Imanaka-Yoshida K, Takahashi K. Expression of tenascin $\mathrm{C}$ in cardiovascular lesions of Kawasaki disease. Cardiovasc Pathol. (2018) 38:25-30. doi: 10.1016/j.carpath.2018.10.005

49. Kentsis A, Shulman A, Ahmed S, Brennan E, Monuteaux MC, Lee Y-H, et al. Urine proteomics for discovery of improved diagnostic markers of Kawasaki disease. EMBO Mol Med. (2013) 5:210-20. doi: 10.1002/emmm.2012 01494

50. Nakamura Y, Yashiro M, Uehara R, Sadakane A, Tsuboi S, Aoyama $\mathrm{Y}$, et al. Epidemiologic features of Kawasaki disease in Japan: results of the 2009-2010 nationwide survey. J Epidemiol. (2012) 22:216-21. doi: 10.2188/jea.JE20110126

51. Park YW, Han JW, Hong YM, Ma JS, Cha SH, Kwon TC, et al. Epidemiological features of Kawasaki disease in Korea, 2006-2008. Pediatr Int. (2011) 53:36-9. doi: 10.1111/j.1442-200X.2010.03178.x

52. Holman RC, Belay ED, Christensen KY, Folkema AM, Steiner CA, Schonberger LB. Hospitalizations for Kawasaki syndrome among children in the United States, 1997-2007. Pediatr Infect Dis J. (2010) 29:483-8. doi: 10.1097/INF.0b013e3181cf8705

53. Harnden A, Mayon-White R, Perera R, Yeates D, Goldacre M, Burgner D. Kawasaki disease in England: ethnicity, deprivation, and respiratory pathogens. Pediatr Infect Dis J. (2009) 28:21-4. doi: 10.1097/INF.0b013e3181812ca4

54. Fildes N, Burns JC, Newburger JW, Klitz W, Begovich AB. The HLA class II region and susceptibility to Kawasaki disease. Tissue Antigens. (1992) 39:99-101. doi: 10.1111/j.1399-0039.1992.tb01915.x

55. Yu H-R, Kuo H-C, Sheen J-M, Wang L, Lin I-C, Wang C-L, et al. A unique plasma proteomic profiling with imbalanced fibrinogen cascade in patients with Kawasaki disease. Pediatr Allergy Immunol. (2009) 20:699-707. doi: 10.1111/j.1399-3038.2008.00844.x

56. Lin M-T, Wang J-K, Yeh J-I, Sun L-C, Chen P-L, Wu J-F, et al. Clinical implication of the C allele of the ITPKC gene SNP rs28493229 in Kawasaki disease: association with disease susceptibility and BCG scar reactivation. Pediatr Infect Dis J. (2011) 30:148-52. doi: 10.1097/INF.0b013e3181f43a4e

57. Peng Q, Chen C, Zhang Y, He H, Wu Q, Liao J, et al. Singlenucleotide polymorphism rs2290692 in the 3'UTR of ITPKC associated with susceptibility to Kawasaki disease in a Han Chinese population. Pediatr Cardiol. (2012) 33:1046-53. doi: 10.1007/s00246-012-0223-x

58. Kuo H-C, Yang KD, Juo S-HH, Liang C-D, Chen W-C, Wang Y$\mathrm{S}$, et al. ITPKC single nucleotide polymorphism associated with the Kawasaki disease in a Taiwanese population. PLoS ONE. (2011) 6:e17370. doi: 10.1371/journal.pone.0017370

59. Onouchi Y, Fukazawa R, Yamamura K, Suzuki H, Kakimoto N, Suenaga T, et al. Variations in ORAIl gene associated with Kawasaki disease. PLoS ONE. (2016) 11:e0145486. doi: 10.1371/journal.pone.0145486

60. Lou J, Zhong R, Shen N, Lu X, Ke J, Duan J, et al. Systematic confirmation study of GWAS-identified genetic variants for Kawasaki disease in a Chinese population. Sci Rep. (2015) 5:8194. doi: 10.1038/srep08194

61. Cheng S-C, Cheng Y-Y, Wu J-L. [Association between gene polymorphism of CD40 gene and coronary artery lesion in Kawasaki disease]. Chin J Contemp Pediatr. (2014) 16:1025-8.

62. Onouchi Y, Ozaki K, Burns JC, Shimizu C, Terai M, Hamada H, et al. A genome-wide association study identifies three new risk loci for Kawasaki disease. Nat Genet. (2012) 44:517-21. doi: 10.1038/ng.2220

63. Chang C-J, Kuo H-C, Chang J-S, Lee J-K, Tsai F-J, Khor CC, et al. Replication and meta-analysis of GWAS identified susceptibility loci in Kawasaki disease confirm the importance of B lymphoid tyrosine kinase (BLK) in 
disease susceptibility. PLoS ONE. (2013) 8:e72037. doi: 10.1371/journal.pone. 0072037

64. Lee Y-C, Kuo H-C, Chang J-S, Chang L-Y, Huang L-M, Chen M-R, et al. Two new susceptibility loci for Kawasaki disease identified through genome-wide association analysis. Nat Genet. (2012) 44:522-5. doi: 10.1038/ng.2227

65. Duan J, Lou J, Zhang Q, Ke J, Qi Y, Shen N, et al. A genetic variant rs1801274 in FCGR2A as a potential risk marker for Kawasaki disease: a case-control study and meta-analysis. PLoS ONE. (2014) 9:e103329. doi: 10.1371/journal.pone.0103329

66. Khor CC, Davila S, Breunis WB, Lee Y-C, Shimizu C, Wright VJ, et al. Genome-wide association study identifies FCGR2A as a susceptibility locus for Kawasaki disease. Nat Genet. (2011) 43:1241-6. doi: 10.1038/ng.981

67. Taniuchi S, Masuda M, Teraguchi M, Ikemoto Y, Komiyama Y, Takahashi H, et al. Polymorphism of Fc gamma RIIa may affect the efficacy of gammaglobulin therapy in Kawasaki disease. J Clin Immunol. (2005) 25:309-13. doi: 10.1007/s10875-005-4697-7

68. Wang W, Lou J, Zhong R, Qi Y, Shen N, Lu X, et al. The roles of Ca2+/NFAT signaling genes in Kawasaki disease: single- and multiple-risk genetic variants. Sci Rep. (2014) 4:5208. doi: 10.1038/srep05208

69. Onouchi Y, Ozaki K, Buns JC, Shimizu C, Hamada H, Honda T, et al. Common variants in CASP3 confer susceptibility to Kawasaki disease. Hum Mol Genet. (2010) 19:2898-906. doi: 10.1093/hmg/ddq176

70. Kuo H-C, Yu H-R, Juo S-HH, Yang KD, Wang Y-S, Liang C-D, et al. CASP3 gene single-nucleotide polymorphism (rs72689236) and Kawasaki disease in Taiwanese children. J Hum Genet. (2011) 56:161-5. doi: 10.1038/jhg.2010.154

71. Choi YM, Shim KS, Yoon KL, Han MY, Cha SH, Kim SK, et al. Transforming growth factor beta receptor II polymorphisms are associated with Kawasaki disease. Korean J Pediatr. (2012) 55:18-23. doi: 10.3345/kjp.2012. 55.1.18

72. Kuo H-C, Onouchi Y, Hsu Y-W, Chen W-C, Huang J-D, Huang Y-H, et al. Polymorphisms of transforming growth factor- $\beta$ signaling pathway and Kawasaki disease in the Taiwanese population. J Hum Genet. (2011) 56:840-5. doi: 10.1038/jhg.2011.113

73. Peng Q, Deng Y, Yang X, Leng X, Yang Y, Liu H. Genetic variants of ADAM17 are implicated in the pathological process of Kawasaki disease and secondary coronary artery lesions via the TGF-B/SMAD3 signaling pathway. Eur $J$ Pediatr. (2016) 175:705-13. doi: 10.1007/s00431-016-2696-8

74. Ban JY, Kim SK, Kang SW, Yoon KL, Chung J-H. Association between polymorphisms of matrix metalloproteinase 11 (MMP-11) and Kawasaki disease in the Korean population. Life Sci. (2010) 86:756-9. doi: 10.1016/j.lfs.2010.03.012

75. Holman RC, Christensen KY, Belay ED, Steiner CA, Effler PV, Miyamura J, et al. Racial/ethnic differences in the incidence of Kawasaki syndrome among children in Hawai' i. Hawaii Med J. (2010) 69:194-7.

76. Fujita Y, Nakamura Y, Sakata K, Hara N, Kobayashi M, Nagai M, et al. Kawasaki disease in families. Pediatrics. (1989) 84:666-9.

77. Kato S, Kimura M, Tsuji K, Kusakawa S, Asai T, Juji T, et al. HLA antigens in Kawasaki disease. Pediatrics. (1978) 61:252-5.

78. Burns JC, Shimizu C, Shike H, Newburger JW, Sundel RP, Baker AL, et al. Family-based association analysis implicates IL- 4 in susceptibility to Kawasaki disease. Genes Immun. (2005) 6:438-44. doi: 10.1038/sj.gene.6364225

79. Maggioli E, Boiocchi C, Zorzetto M, Mannarino S, Bossi G, Cuccia M. HLA class III genes involvement in Kawasaki disease: a case-control study in Caucasian population. Int J Immunogenet. (2014) 41:44-53. doi: $10.1111 / \mathrm{iji} .12077$

80. Ichida KHF. Utility of TNF- $\alpha$ as a biomarker and the possibility of anti-TNF- $\alpha$ therapy for Kawasaki disease. Pediatr Ther. (2014) 5:1-6. doi: 10.4172/2161-0665.1000257

81. Huang F-Y, Lee Y-J, Chen M-R, Hsu C-H, Lin S-P, Sung T-C. Polymorphism of transmembrane region of MICA gene and Kawasaki disease. Exp Clin Immunogenet. (2000) 17:130-7. doi: 10.1159/000019132

82. Onouchi Y, Tamari M, Takahashi A, Tsunoda T, Yashiro M, Nakamura $\mathrm{Y}$, et al. A genomewide linkage analysis of Kawasaki disease: evidence for linkage to chromosome 12. J Hum Genet. (2007) 52:179-90. doi: 10.1007/s10038-006-0092-3

83. Onouchi Y, Gunji T, Burns JC, Shimizu C, Newburger JW, Yashiro M, et al. ITPKC functional polymorphism associated with Kawasaki disease susceptibility and formation of coronary artery aneurysms. Nat Genet. (2008) 40:35-42. doi: 10.1038/ng.2007.59

84. Che D, Pi L, Fang Z, Xu Y, Cai M, Fu L, et al. abcc4 variants modify susceptibility to Kawasaki Disease in a Southern Chinese population. Dis Markers. (2018) 2018:1-7. doi: 10.1155/2018/8638096

85. Shimizu C, Oharaseki T, Takahashi K, Kottek A, Franco A, Burns JC. The role of TGF- $\beta$ and myofibroblasts in the arteritis of Kawasaki disease. Hum Pathol. (2013) 44:189-98. doi: 10.1016/j.humpath.2012.05.004

86. Kuo H-C, Chao M-C, Hsu Y-W, Lin Y-C, Huang Y-H, Yu H-R, et al. CD40 gene polymorphisms associated with susceptibility and coronary artery lesions of Kawasaki disease in the Taiwanese population. Sci World J. (2012) 2012:1-5. doi: $10.1100 / 2012 / 520865$

87. Aukrust P, Müller F, Ueland T, Berget T, Aaser E, Brunsvig A, et al. Enhanced levels of soluble and membrane-bound CD40 ligand in patients with unstable angina. Possible reflection of T lymphocyte and platelet involvement in the pathogenesis of acute coronary syndromes. Circulation. (1999) 100:614-20. doi: 10.1161/01.CIR.100.6.614

88. Wang C-L, Wu Y-T, Liu C-A, Lin M-W, Lee C-J, Huang L-T, et al. Expression of CD40 ligand on CD4+ T-cells and platelets correlated to the coronary artery lesion and disease progress in Kawasaki disease. Pediatrics. (2003) 111:E140-147. doi: 10.1542/peds.111.2.e140

89. Lee J-K, Hong YM, Jang GY, Yun SW, Yu JJ, Yoon KL, et al. Consortium-based genetic studies of Kawasaki disease in Korea: Korean Kawasaki disease genetics consortium. Korean Circ J. (2015) 45:443. doi: 10.4070/kcj.2015.45.6.443

90. Chi H, Huang F-Y, Chen M-R, Chiu N-C, Lee H-C, Lin S-P, et al. ITPKC gene SNP rs28493229 and Kawasaki disease in Taiwanese children. Hum Mol Genet. (2010) 19:1147-51. doi: 10.1093/hmg/ddp586

91. Kuo HC, Lin YJ, Juo SHH, Hsu YW, Chen WC, Yang KD, et al. Lack of association between ORAI1/CRACM1 Gene Polymorphisms and Kawasaki disease in the Taiwanese children. J Clin Immunol. (2011) 31:650-5. doi: $10.1007 / \mathrm{s} 10875-011-9524-8$

92. Zhang W. Gene-Gene Associations with the susceptibility of Kawasaki disease and coronary artery lesions. PLOS ONE. (2015) 10:e0143056. doi: 10.1371/journal.pone.0143056

93. Li Z, Han D, Jiang J, Chen J, Tian L, Yang Z. Association of PECAM-1 gene polymorphisms with Kawasaki disease in Chinese children. Dis Markers. (2017) 2017:1-6. doi: 10.1155/2017/2960502

94. Yun KW, Lee JY, Yun SW, Lim IS, Choi ES. Elevated serum level of microRNA (miRNA)-200c and miRNA-371-5p in children with Kawasaki disease. Pediatr Cardiol. (2014) 35:745-52. doi: 10.1007/s00246-013-0846-6

95. Rong X, Ge D, Shen D, Chen X, Wang X, Zhang L, et al. miR-27b suppresses endothelial cell proliferation and migration by targeting Smad7 in Kawasaki disease. Cell Physiol Biochem Int J Exp Cell Physiol Biochem Pharmacol. (2018) 48:1804-14. doi: 10.1159/000492354

96. Wright VJ, Herberg JA, Kaforou M, Shimizu C, Eleftherohorinou H, Shailes H, et al. Diagnosis of Kawasaki disease using a minimal wholeblood gene expression signature. JAMA Pediatr. (2018) 172:e182293-e182293. doi: 10.1001/jamapediatrics.2018.2293

97. Kim J, Shimizu C, Kingsmore SF, Veeraraghavan N, Levy E, Ribeiro dos Santos AM, et al. Whole genome sequencing of an African American family highlights toll like receptor 6 variants in Kawasaki disease susceptibility. PLoS ONE. (2017) 12:e0170977. doi: 10.1371/journal.pone.01 70977

Conflict of Interest Statement: The authors declare that the research was conducted in the absence of any commercial or financial relationships that could be construed as a potential conflict of interest.

Copyright (c) 2019 Chaudhary, Nameirakpam, Kumrah, Pandiarajan, Suri, Rawat and Singh. This is an open-access article distributed under the terms of the Creative Commons Attribution License (CC BY). The use, distribution or reproduction in other forums is permitted, provided the original author(s) and the copyright owner(s) are credited and that the original publication in this journal is cited, in accordance with accepted academic practice. No use, distribution or reproduction is permitted which does not comply with these terms. 